\title{
PENGARUH LEVERAGE TERHADAP AUDIT REPORT LAG DENGAN PROFITABILITAS SEBAGAI VARIABEL MEDIASI PADA PERUSAHAAN IDX30 TAHUN 2015-2018
}

\author{
Joice Idarumata Aritonang ${ }^{1}$ Valentine Siagian ${ }^{2}$
}

Article history:

Submitted:

2 Agustus 2021

Revised:

22 Agustus 2021

Accepted:

23 Agustus 2021

\section{Keywords:}

Leverage;

Profitability;

Audit Report Lag.

\section{Kata Kunci:}

Leverage;

Profitabiltas;

Audit Report Lag.

\section{Koresponding:}

Fakultas Ekonomi, Universitas Advent Indonesia, Bandung, Indonesia

Email: joiceart@gmail.com
Abstract

This study is conducted with the aim of knowing the effect of leverage on audit report lag with profitability as a mediating variable. The population taken is IDX30 companies listed on the Indonesia Stock Exchange (IDX) for the 2015-2018 period using the purposive sampling method. The number of samples used is 68 samples from 17 listed companies. The analytical method used in this research is descriptive statistical analysis, classical assumption test, and path analysis. The results obtained based on the tests that have been carried out are that leverage has a significant negative effect on audit report lag, which means that the higher the leverage, the lower the audit report lag. While profitability has no effect on audit report lag and leverage also has no effect on profitability. However, it was found that leverage had no significant effect on audit report lag through profitability mediation.

\section{Abstrak}

Penelitian ini dilakukan dengan tujuan untuk mengetahui pengaruh leverage terhadap audit report lag dengan profitabilitas sebagai variabel mediasi. Populasi yang diambil adalah perusahaan IDX30 yang terdaftar di Bursa Efek Indonesia (BEI) periode 2015-2018 dengan menggunakan metode purposive sampling. Jumlah sampel yang digunakan adalah 68 sampel dari 17 perusahaan yang tercatat. Metode analisa yang digunakan dalam penelitian ini yaitu analisa statistik deskriptif, uji asumsi klasik, dan analisis jalur. Hasil yang didapatkan berdasarkan uji yang telah dilakukan adalah leverage berpengaruh negatif signifikan terhadap audit report lag dengan arti semakin tinggi leverage semakin rendah audit report lag. Sedangkan profitabilitas tidak berpengaruh terhadap audit report lag dan leverage juga tidak berpengaruh terhadap profitabilitas. Tetapi didapati leverage tidak berpengaruh signifikan terhadap audit report lag melalui mediasi profitabilitas.

Fakultas Ekonomi, Universitas Advent Indonesia, Bandung, Indonesia ${ }^{2}$ 


\section{PENDAHULUAN}

Laporan keuangan adalah salah satu hal terpenting dalam suatu perusahaan. Dibutuhkan ketepatan dalam menyajikan dan menyampaikan laporan keuangan perusahaan. Banyak pihak yang membutuhkan informasi akuntansi melalui laporan keuangan, terutama pihak investor (Bawono \& Ariani, 2018). Kerap kali para investor membutuhkan laporan keuangan sebagai acuan dalam berinvestasi. Apabila terjadi keterlambatan dalam menyampaikan laporan keuangan perusahaan maka akan menimbulkan rasa keraguan para investor untuk berinvestasi.

Informasi akuntansi yang berbentuk laporan keuangan merupakan suatu bentuk pertanggungjawaban suatu perusahaan kepada publik atas penggunaan sumber daya yang dimilikinya. Tetapi oleh karena pesatnya pertumbuhan dan perkembangan pasar modal menyebabkan persaingan dunia bisnis dalam penyediaan dan perolehan informasi sebagai dasar dalam pengambilan keputusan akan semakin kompetitif (Angruningrum \& Wirakusuma, 2013).

Rasa kepercayaan yang dimiliki oleh para investor bergantung pada laporan keuangan perusahaan yang disampaikan sebagai bentuk infomasi bagi mereka. Perusahaan pastinya akan berusaha memberikan kualitas informasi yang baik melalui laporan keuangan yang dipublikasikan kepada publik yang memperlihatkan perusahaan memiliki kemampuan mengahasilkan laba yang baik di masa depan (Sintyana \& Artini, 2018). Laporan keuangan perusahaan yang baik adalah laporan keuangan yang dapat memberikan infomasi yang relevan, jelas, dan akurat. Jika terjadi keterlambatan dalam menyampaikan laporan keuangan perusahaan akan mempengaruhi pihak-pihak yang berkepentingan dalam pengambilan keputusan. Apabila hal ini terjadi pada para investor maka akan menjadi penyebab penurunan rasa kepercayaan investor. Kemungkinan hal yang akan terjadi dilihat dari sisi pandang pihak investor adalah terjadinya penundaan bahkan pembatalan pembelian dan penjualan saham pada perusahaan sebelum laporan keuangan perusahaan dipublikasikan kepada publik. Hal ini pun akan berdampak pada ketidakstabilan harga saham perusahaan (Chasanah \& Sagoro, 2017).

Laporan keuangan yang terdapat di Bursa Efek Indonesia (BEI) akan disampaikan kepada publik dan pastinya harus melalui proses pemeriksaan terlebih dahulu oleh auditor independen sesuai dengan Standar Akuntansi Keuangan (SAK). Tujuan laporan keuangan diaudit oleh auditor independen adalah untuk menilai kewajaran atau kelayakan perusahaan dalam menyajikan laporan keuangannya. Kewajaran atau kelayakan tersebut akan diketahui pada saat auditor independen memberikan opini audit dalam laporan keuangan perusahaan yang sudah diperiksa. Tetapi dibutuhkan waktu yang cukup panjang dalam melakukan proses pemeriksaan laporan keuangan perusahaan yang dapat disebabkan oleh banyak faktor.

Fenomena keterlambatan dalam penyampaian laporan keuangan masih saja terjadi. Sesuai dengan informasi yang diperoleh dari situs Kontan, disebutkan bahwa keterlambatan dalam mempublikasikan 
laporan keuangan ternyata terjadi pada enam perusahaan yang tercatat di BEI tahun 2019. Disebutkan bahwa keenam perusahaan ini belum melakukan kewajibannya sehubungan dengan penyampaian laporan keuangan per 30 September 2019 dan merajuk pada ketentuan II.6.3. Sanksi yang dikenakan pada enam emiten ini berupa Peringatan Tertulis III dan adanya denda yang dikenakan sebanyak Rp. 150 juta. Hingga 30 Januari 2020, denda yang dikenakan belum juga dibayarkan dan laporan keuangan enam emiten per September 2019 tersebut masih belum disampaikan. Sehingga otoritas bursa mengambil tindakan untuk memperpanjang masa suspensi 6 perusahaan tersebut (Puspitasari, 2020).

Leverage atau rasio solvabilitas merupakan kesanggupan perusahaan dalam membayar semua kewajiban finansial jangka panjang ataupun jangka pendeknya (Cahyanti dkk., 2016) dan bertahan dalam rentang waktu yang panjang (Tannuka, 2018). Auditor perlu berhati-hati dan cermat dalam melakukan proses audit laporan keuangan suatu perusahaan apabila perusahaan memiliki proporsi hutang lebih tinggi terhadap total aktiva atau ekuitas yang dimiliki karena hal tersebut dapat mempengaruhi kelikuiditasan perusahaan. Tingginya tingkat proporsi hutang umumnya berpengaruh besar terhadap risiko keuangan perusahaan.

Tingkat profitabilitas merupakan kesanggupan suatu perusahaan dalam menghasilkan keuntungan baik melalui aset atau modal yang dimiliki oleh perusahaan (Octaviani \& Komalasarai, 2017). Tingkat profitabilitas yang rendah atau kerugian yang dialami perusahaan merupakan salah satu penyebab suatu perusahaan tidak tepat waktu menyampaikan hasil audit laporan keuangan (Suparsada \& Putri, 2017). Sudah menjadi hal yang umum untuk diketahui apabila suatu perusahaan yang mendapatkan keuntungan atau laba dalam suatu periode tertentu maka perusahaan tersebut akan dengan segera menyampaikan laporan keuangannya pada publik karena hal ini dianggap sebagai sinyal yang baik sehingga pihak-pihak yang memiliki kepentingan dapat menggunakan informasi akuntansi berupa laporan keuangan tersebut dalam pengambilan keputusan.

Tingkat leverage juga dapat diartikan sebagai sebesar jauh sebuah perusahaan dapat membiayai operasional perusahaan tersebut menggunakan hutang perusahaan (Ngadiman \& Puspitasari, 2017). Apabila suatu perusahaan memiliki tingkat hutang yang semakin tinggi maka risiko yang harus dihadapi perusahaan tersebut pun akan semakin besar. Dalam penelitian yang dilakukan peneliti saat ini menggunakan indikator Debt to Asset Ratio (DAR) sebagai rasio perhitungan leverage. DAR merupakan rasio untuk mengukur perbandingan rasio jumlah hutang dengan jumlah aset atau aktiva perusahaan. Dengan adanya rasio ini maka dapat mengetahui seberapa sanggup suatu perusahaan dapat membiayai kewajibannya menggunakan aktiva kepada kreditor. Semakin tinggi rasio leverage akan berdampak pada tingginya tingkat risiko terhadap kerugiaan yang dimiliki perusahaan (Firmansyah \& Amanah, 2020).

Rasio profitabilitas merupakan suatu tolak ukur dalam menentukan keberhasilan perusahaan dengan menghasilkan keuntungan. Tingkat profitabilitas menggambarkan 
keefektifitasan yang harus didapatkan oleh suatu operasional perusahaan (Dura, 2017). Keberhasilan suatu perusahaan dalam menghasilkan profit atau keuntungan dapat dilihat dari tingkat profitabilitas yang ada dalam perusahaan tersebut. Merupakan suatu hal yang baik apabila suatu perusahaan memiliki tingkat profitabilitas yang tinggi. Perusahaan pastinya dengan segera memberitahukan kabar baik ini kepada pihak yang memiliki kepentingan (Himawan \& Amanda, 2015). Indikator Return on Asset (ROA) dipilih sebagai rasio perhitungan profitabilitas dalam penelitian ini oleh peneliti. ROA bertujuan untuk mengetahui berapa banyak tingkat pengembalian dan laba yang diperoleh suatu perusahaan dengan menggunakan aset atau aktiva sendiri.

\section{Adapun definisi audit report lag} menurut Dewangga \& Laksito (2015) yaitu rentang waktu lamanya penyelesaian proses audit sampai tanggal laporan audit diterbitkan. Selisih waktu yang diperlukan dalam proses penyelesaian pemeriksaan laporan keuangan suatu perusahaan dari tanggal tutup buku yaitu per 31 Desember hingga tanggal diterbitkannya laporan keuangan peruasahaan yang telah diaudit oleh auditor independen. Sastrawan \& Latrini (2016) berpendapat bahwa rentang waktu dalam menyajikan laporan keuangan kepada publik harus sesuai dengan ketetapan dan ketentuan yang telah dibentuk oleh Bapepam. Lamanya waktu untuk menyelesaikan proses pengauditan dari tanggal tutup buku perusahaan sampai dengan tanggal yang tercatat dalam laporan keuangan yang telah diaudit diketahui sebagai audit report lag.
Bahri dkk., (2018) telah melakukan penelitiannya dan menyatakan bahwa leverage atau rasio solvabilitas memiliki pengaruh terhadap audit report lag. Terakait dengan hal tersebut, penelitian yang dilaksanakan oleh Harjanto (2017) sangat mendukung yang menjelaskan bahwa di antara hubungan leverage dengan audit report lag terdapat pengaruh signifikan. Tetapi hal tersebut berbanding terbalik dengan hasil penelitian Menajang dkk., (2019) di mana menjelaskan bahwa di antara leverage dan audit report lag tidak ada pengaruh yang signifikan. Hasil penelitian yang dinyatakan oleh Tannuka (2018); Chasanah \& Sagoro (2017); dan Lisdara dkk., (2019) ternyata juga sejalan yang menjelaskan bahwa leverage ternyata tidak memiliki pengaruh yang signifikan terhadap audit report lag.

Penelitian yang dilaksanakan oleh Tuladang \& Tipa (2020) membuktikan bahwa profitabilitas memiliki pengaruh yang signifikan terhadap audit report lag. Hal tersebut didukung oleh penelitian yang dijalankan oleh Dura (2017) yang juga menyatakan bahwa di antara hubungan profitabilitas terhadap audit report lag terdapat pengaruh yang signifikan. Berbeda halnya dengan hasil penelitian yang didapatkan Debbianita dkk., (2018) yang menjelaskan bahwa profitabilitas tidak memiliki pengaruh yang signifikan terhadap audit report lag. Hal ini selaras dengan penelitian Sastrawan \& Latrini (2016); David \& Aprilyanti (2018) menerangkan bahwa tidak adanya pengaruh yang signifikan terkait profitabilitas terhadap audit report lag. Adapun hipotesis dalam penelitian ini yakni: 
$\mathrm{H}_{1}$ : Leverage mempengaruhi Audit Report Lag

$\mathrm{H}_{2}$ : Profitabilitas mempengaruhi Audit Report Lag

$\mathrm{H}_{3}$ : Leverage tidak mempengaruhi Profitabilitas

$\mathrm{H}_{4}$ : Leverage mempengaruhi Audit Report Lag melalui Profitabilitas

\section{METODE PENELITIAN}

Populasi dalam penelitian ini adalah laporan keuangan tahunan perusahaan IDX30 yang terdaftar di Bursa Efek Indonesia (BEI) periode 2015-2018. Sampel yang digunakan dalam penelitian ini diambil dari laporan tahunan perusahaan IDX30 yang terdaftar di BEI periode 2015-2018 dengan menggunakan teknik purposive sampling di mana sampel yang diambil menggunakan kriteria tertentu yang ditetapkan guna mencapai maksud penelitian. Kriteria yang dipergunakan ada 2 ialah perusahaan yang terdaftar di BEI dan tergolong perhitungan indeks IDX30 secara berturut-turut dalam periode tahun 2015-2018 dan juga perusahaan yang memiliki laba positif dan tidak memiliki kerugian secara berturut-turut dalam periode tahun 20152018. Sehingga didapatkan sebanyak 68 sampel yang akan diolah dari emiten dengan kode ADRO, ASII, BBCA, BBNI, BBRI, BMRI, GGRM, ICBP, INDF, INTP, KLBF, LPPF, PGAS, SMGR, TLKM, UNTR, dan UNVR.

Variabel independen yang digunakan dalam penelitian ini adalah leverage. Terkait dengan leverage, Debt to Asset Ratio (DAR) dipilih menjadi indikator perhitungan rasio leverage dalam penelitian ini. DAR dapat diartikan sebagai kesanggupan suatu perusahaan membiayai aktivanya menggunakan hutang yang dimiliki.

DAR $=$ Total Debt $/$ Total Asset.

Profitabilitas dengan indikator Return on Asset (ROA) dijadikan sebagai variabel mediasi dalam penelitian ini dan audit report lag digunakan sebagai variabel dependen. ROA memiliki artian sebagai rasio yang dapat menilai kesanggupan suatu perusahaan memperoleh keuntungan menggunakan aset yang dimiliki.

ROA = Net Income/Total Asset

Analisa data yang digunakan dalam penelitian ini yaitu analisa statistik deskriptif, uji asumsi klasik (uji normalitas, uji heterokedastitstas, uji autokorelasi, dan uji multikolienaritas), dan analisis jalur karena pada penelitian ini terdapat variabel independen, variabel dependen, dan variabel yang memediasi (intervening).

\section{HASIL DAN PEMBAHASAN}

Tabel 1. Statistik Deskriptif

\begin{tabular}{llllll}
\hline & N & Min. & $\begin{array}{c}\text { Max } \\
\text {. }\end{array}$ & Mean & $\begin{array}{c}\text { Std. } \\
\text { Deviation }\end{array}$ \\
\hline DAR & 68 &, 02 &, 87 &, 4691 &, 27556 \\
\hline LAG & 68 & 15 & 119 & 58,15 & 21,569 \\
\hline ROA & 68 &, 02 &, 46 &, 1122 &, 11084 \\
\hline $\begin{array}{l}\text { Valid N } \\
\text { (listwise) }\end{array}$ & 68 & & & & \\
\hline
\end{tabular}

Sumber: Data olahan, 2021

Hasil analisa statistik deskriptif menunjukkan bahwa secara keseluruhan DAR pada perusahaan IDX30 adalah 46,91\%. Nilai minimum DAR ialah 0,02 yang berasal dari 
emiten KLBF. Sedangkan nilai maksimum ialah 0,87 berasal dari emiten BBRI dan BMRI. Didapati tingkat profitabilitas berdasarkan rasio Return on Asset sebesar $11,22 \%$ sedangkan nilai minimum dan maksimum ROA secara berturut-turut sebesar 0,02 dan 0,46 yang berasal dari emiten BMRI dan LPPF yang menunjukkan bahwa perusahaan IDX30 memiliki kemampuan menghasilkan berdasarkan aset yang baik. Otoritas Jasa Keuangan (OJK) telah menetapkan batas standar jumlah hari dalam audit report lag adalah 90 hari dan ditemukan bahwa rata-rata jumlah hari dalam audit report lag perusahaan IDX30 ialah 58,15 hari. Sedangkan nilai minimum dan maksimum audit report lag secara beruturut-turut ialah 15 hari yang berasal dari emiten BBNI dan 119 hari yang berasal dari emiten TLKM. Dapat disimpulkan bahwa perusahaan IDX30 dalam penelitian memiliki kondisi keuangan yang baik yakni mampu meghasilkan laba dan tingkat hutang yang baik serta tidak terlambat dalam mengeluarkan laporan audit yang telah diperiksa oleh auditor.

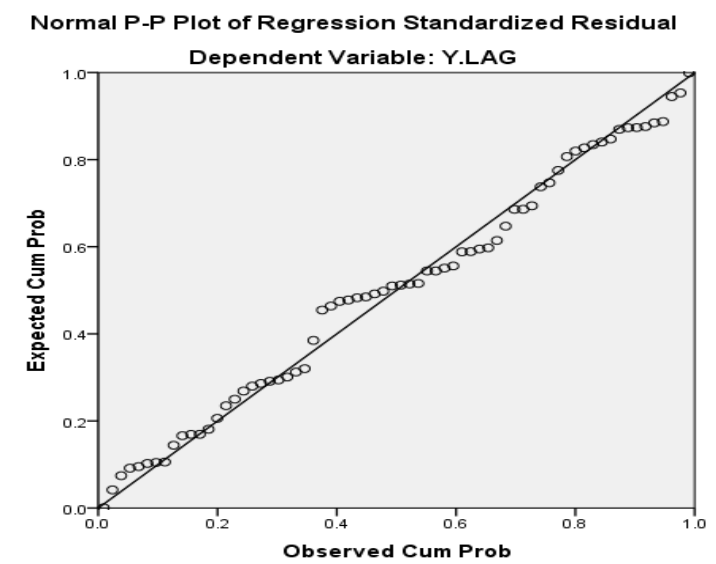

Sumber : Data olahan, 2021

Gambar 1. Uji Normalitas
Melalui uji normalitas dapat disimpulkan bahwa data terdistribusi normal dan uji diterima terlihat bahwa titik plot berada di antara garis diagonal.

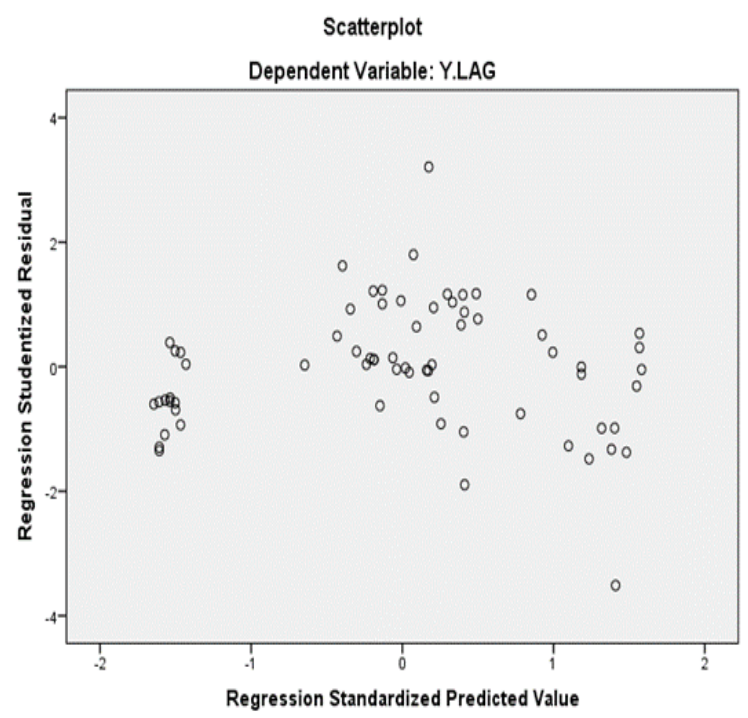

Sumber: Data olahan, 2021

Gambar 2.

Uji Heterokedastisitas

Melalui uji heterokedastisitas dapat disimpulkan bahwa uji diterima dan tidak terjadi heterokedastisitas. Hal ini dapat dibuktikan bahwa titik plot tersebar dan tidak membentuk pola.

Tabel 2.

Uji Auto Korelasi

\begin{tabular}{ll}
\hline Model & Durbin- Watson \\
\hline 1 & 1,790 \\
\hline a. Predictors: (Constant), ROA, DAR \\
b. Dependent Variable: LAG
\end{tabular}

Sumber: Data olahan, 2021

Dari hasil uji auto korelasi menunjukkan bahwa DW 1,790 berada di antara -2 dan 2, maka didapati bahwa uji diterima dan tidak terjadi autokorelasi. 
Tabel 3.

Uji Multikolinearitas

\begin{tabular}{|c|c|c|}
\hline \multirow[b]{2}{*}{ Model } & \multicolumn{2}{|c|}{ Collinearity Statistics } \\
\hline & Tolerance & VIF \\
\hline 1 DAR & 1,000 & 1,000 \\
\hline ROA & 1,000 & 1,000 \\
\hline
\end{tabular}

a. Dependent Variable: LAG

Sumber: Data olahan, 2021

Dari skema pada uji multikolinearitas dapat diketahui bahwa $\mathrm{VIF}<10$ dan nilai tolerance $>0,10$, kemudian didapati bahwa uji diterima dan tidak terbentuk multikolinearitas.

Melalui hasil penelitian yang didapat melalui uji signifikan $t$ didapati pada model pertama (Tabel 1) menunjukkan tidak adanya pengaruh yang signifikan dari leverage dengan indikator DAR terhadap profitabilitas dengan indikator ROA. Pada hasil selanjutnya didapati bahwa ada pengaruh yang signifikan dari DAR dan audit report lag. Hal ini dapat dilihat dari uji signifikan $\mathrm{t}$ menunjukkan bahwa besar t-hitung yaitu 4,912 dan nilai signifikansi adalah 0,000 pada tingkat signifikan 5\%. Pada model selanjutnya (Tabel 2) didapati bahwa leverage yang telah dimoderasi dengan profitabilitas ternyata adanya pengaruh yang signifikan dengan nilai Sig. 0,000 pada tingkat signifikan $5 \%$ sedangkan ROA tidak berpengaruh signifikan dengan nilai Sig. 0,098 pada level signifikansi 5\%.

Penelitian ini menggunakan tahapan analisis jalur untuk menentukan pengaruh langsung, tidak langsung, dan juga total untuk mengetahui pengaruh mediasi. Melalui hasil analisis menjelaskan bahwa leverage (DAR) memiliki pengaruh secara langsung ataupun tidak langsung terhadap variabel audit report lag melalui variabel ROA.

Tabel 4.

Analisis Regresi Substruktur 1

\begin{tabular}{|c|c|c|c|c|c|}
\hline \multirow[b]{2}{*}{ Model } & \multicolumn{5}{|c|}{ Unstandardized Coefficients Standardized Coefficients } \\
\hline & $\mathbf{B}$ & Std. Error & Beta & $\mathbf{T}$ & Sig. \\
\hline 1 (Constant) &, 110 & ,027 & & 4,096 & ,000 \\
\hline DAR & ,004 &, 050 & 011 & ,090 & ,929 \\
\hline
\end{tabular}

a. Dependent Variable: ROA

Sumber: Data olahan, 2021

Tabel 5.

Analisis Regresi Substruktur 2

\begin{tabular}{|c|c|c|c|c|c|}
\hline \multirow[b]{2}{*}{ Model } & \multicolumn{5}{|c|}{ Unstandardized Coefficients Standardized Coefficients } \\
\hline & $\overline{\mathbf{B}}$ & Std. Error & Beta & $\mathbf{T}$ & Sig. \\
\hline 1 (Constant) & 77,145 & 4,477 & & 17,230 & ,000 \\
\hline DAR & $-40,497$ & 8,245 &,- 517 & $-4,912$ &, 000 \\
\hline 2 (Constant) & 73,402 & 4,946 & & 14,840 & ,000 \\
\hline DAR & $-40,648$ & 8,134 &,- 519 & $-4,997$ & 000 \\
\hline ROA & 33,988 & 20,221 &, 175 & 1,681 & ,098 \\
\hline
\end{tabular}

a. Dependent Variable: LAG

Sumber: Data olahan, 2021 
Hasil pengaruh langsung antara DAR dan audit report lag sebesar -40,648. Sedangkan besarnya hasil pengaruh tidak langsung yang dibuat adalah 0,1359 dan total pengaruh ROA terhadap audit report lag adalah -40,5121. Peneliti akan menggunakan perhitungan sobel test untuk mengetahui apakah ada pengaruh yang signifikan atau tidak oleh variabel mediasi.

$$
\begin{aligned}
S p 2 p 3 & =\sqrt{ } p 3^{2} S p 2^{2}+p 2^{2} S p 3^{3}+S p 2^{2} S p 3^{2} . .(3) \\
& =\sqrt{ }(33,988)^{2}(0,050)^{2}+ \\
& (0,004)^{2}(20,2221)^{2}+(0,050)^{2}(20,221)^{2} \\
& =\sqrt{ } 3,916 \\
& =1,9789
\end{aligned}
$$

Berdasarkan hasil perhitungan maka t hitung adalah:

$$
\begin{aligned}
T_{\text {hitung }} & =P 2 P 3 / S p 2 P 3 \ldots \ldots \ldots \ldots \ldots \ldots \ldots \ldots(4) \\
& =0,1360 / 1,9789 \\
& =0,0687
\end{aligned}
$$

Diketahui hasil melalui sobel test yang telah dilakukan bahwa thitung sebesar 0,0687 yang ternyata lebih kecil dari $t_{\text {tabel }}$ sebesar 1,997 dengan nilai signifikansi 5\%. Maka dengan ini penulis menyimpulkan bahwa profitabilitas dengan indikator ROA tidak berpengaruh sebagai variabel mediasi bagi hubungan antara leverage (DAR) terhadap audit report lag.

Sesuai dengan hasil olahan data yang telah dilakukan ternyata didapatkan bahwa terdapat pengaruh negatif signifikan antara leverage dengan indikator DAR dan audit report lag terbukti dari hasil yang didapatkan. Terkait dengan hasil yang didapatkan maka dapat dinyatakan bahwa hipotesa pertama $\left(\mathrm{H}_{1}\right)$ diterima. Dibuktikan dengan hasil t- hitung sebesar -4,912 dan nilai signifikansi 0,000 pada level sig. 5\%. Dapat diartikan bahwa semakin besar tingkat leverage maka akan semakin kecil tingkat audit report lag. Disimpulkan bahwa semakin tinggi atau besar proporsi hutang yang dimiliki perusahaan maka hasil laporan keuangan yang diaudit akan semakin cepat untuk disampaikan yang terjadi dalam perusahaan IDX30. Hal ini sesuai dengan hasil penelitian yang telah dilakukan oleh Tampubolon \& Siagian (2020) dengan penelitian di perusahaan real estate, property, dan konstruksi bangunan di Bursa Efek Indonesia dan Artaningrum \& Wasita (2020) dengan penelitian di perusahaan perbankan di mana mungkin beberapa perusahaan tersebut termasuk dalam perusahaan yang memiliki likuiditas tinggi dan termasuk dalam perusahaan IDX30 sehingga hasil penelitian yang didapatkan pun sejalan. Namun bertentangan dengan hasil penelitan yang dijalankan Kusumah dkk., (2021) dengan penelitian di perusahaan tambang di BEI dan Sudradjat dkk., (2020) dengan penilitian yang dilakukan pada perusahaan manufaktur di BEI yang menjelaskan bahwa tidak adanya pengaruh yang signifikan antara leverage terhadap audit report lag.

Hipotesa kedua $\left(\mathrm{H}_{2}\right)$ dalam penelitian ini menyatakan terdapat pengaruh profitabilitas terhadap audit report lag. Profitabilitas merupakan tingkat kesanggupan perusahaan dalam menghasilkan keuntungan atau laba berdasarkan kemampuannya. Berdasarkan penelitian yang dijalankan, yang dapat disimpulkan melalui hasil penelitian bahwa tidak adanya pengaruh yang signifikan antara hubungan profitabilitas dengan 
variabel ROA terhadap audit report lag berdasarkan hasil penelitian yang menunjukkan nilai signifikansi 0,098 . Terkait dengan hasil penelitian yang didapatkan maka $\mathrm{H}_{0}$ diterima dan $\mathrm{H}_{\mathrm{a}}$ ditolak. Dapat dimengerti bahwa tingkat keuntungan yang dimiliki perusahaan sama sekali tidak mempengaruhi cepat atau lambatnya laporan keuangan yang diaudit untuk disampaikan dalam perusahaan IDX30. Penelitian yang telah dilaksanakan oleh Abbas dkk., (2019) pada perusahaan manufaktur di BEI ternyata sejalan dengan hasil penelitian ini dan Effendi (2018) pada perusahaan consumer goods di BEI. Tetapi bertentangan dengan hasil dari penelitian yang dijalankan oleh Fujianti \& Satria (2020) pada perusahaan manufaktur di BEI dan Arifuddin dkk., (2017) yang juga melakukan penelitiannya pada perusahaan manufaktur di BEI menyatakan hasil yang signifikan terkait pengaruh profitabilitas terhadap audit report lag.

Dalam hipotesa $3\left(\mathrm{H}_{3}\right)$ menjelaskan bahwa leverage tidak memiliki pengaruh terhadap profitabilitas dan menurut hasil data yang telah diolah menunjukkan tidak adanya pengaruh yang signifikan dari DAR terhadap ROA dan menunjukkan bahwa hipotesa tersebut diterima. Hal ini ditunjukkan dengan hasil t-hitung 0,929 >0,05, secara empiris hal ini menunjukkan bahwa tingkat hutang yang dimiliki oleh perusahaan terindeks IDX30 pada tahun 2015-2018 sama sekali tidak mempengaruhi tingkat keuntungan atau profit yang didapatkan perusahaan. Hasil penelitian ini sesuai dengan penelitian yang dilakukan oleh Gunde dkk., (2017) pada perusahaan manufaktur sub industri food and beverages di BEI tetapi bertolak belakang dengan hasil penelitian yang dilakukan Jafira dkk., (2021) pada perusahaan BUMN yang terdaftar di BEI.

Hasil penelitian juga menunjukkan bahwa variabel profitabilitas dengan indikator ROA tidak mampu memediasi pengaruh variabel leverage dengan indikator DAR terhadap audit report lag. Pada hasil hipotesa sebelumnya juga diketahui bahwa leverage tidak mempengaruhi profitabilitas. Dengan ini dapat disimpulkan bahwa hipotesa $4\left(\mathrm{H}_{4}\right)$ yang dinyatakan oleh peneliti mengenai pengaruh leverage terhadap audit report lag melalui profitabilitas ditolak. Dibuktikan melalui hasil sobel test bahwa t-hitung 0,0687 lebih kecil dari t-tabel 1,997.

\section{SIMPULAN DAN SARAN}

Simpulan yang dapat ditarik melalui hasil penelitian yang telah didapatkan maka disimpulkan melalui 68 sampel data yang digunakan dari 17 perusahaan IDX30 yang terdaftar di BEI periode 2015-2018 bahwa dalam hubungan antara leverage atau rasio solvabilitas dengan audit report lag terdapat pengaruh yang signifikan. Semakin tingginya tingkat rasio solvabilitas atau leverage maka semakin cepat pula laporan keuangan yang sudah diaudit untuk dipublikasikan dan disampaikan kepada publik. Hasil dari penelitian ini juga menunjukkan bahwa ROA sebagai indikator dari variabel profitabilitas tidak memiliki pengaruh terhadap audit report lag. Hal ini menunjukkan bahwa pada perusahaan IDX30 tidak adanya pengaruh yang diberikan pada cepat atau lambatnya laporan keuangan yang diaudit untuk 
Pengaruh Leverage Terhadap Audit Report Lag dengan ... Joice Idarumata Aritonang \& Valentine Siagian

diselesaikan oleh tingkat keuntungan yang dimiliki oleh perusahaan. Diketahui pula bahwa ternyata dalam hubungan leverage terhadap profitabilitas tidak adanya pengaruh signifikan yang dapat disimpulkan bahwa tingkat hutang atau kewajiban yang dimiliki oleh perusahaan pada IDX30 tidak memiliki pengaruh terhadap tingkat profitabilitas yang dimiliki oleh perusahaan tersebut. Berkaitan dengan hasil penelitian dan juga kesimpulan yang telah didapatkan, diketahui bahwa dalam hubungan di antara leverage terhadap audit report lag, rasio profitabilitas tidak sanggup menjadi variabel mediasi.

Dianjurkan untuk para peneliti yang akan meneliti lebih lanjut agar dapat menambahkan variabel penelitian yang beragam. Hal tersebut dilakukan dengan tujuan agar dalam penelitian selanjutnya dapat diketahui faktor-faktor apa saja yang memiliki kemungkinan untuk berpengaruh terhadap audit report lag. Diharapkan bagi peneliti selanjutnya dapat melanjutkan penelitian dan dapat menambahkan variabel mediasi untuk mengetahui apakah variabel tersebut dapat memperkuat atau memperlemah hubungan di antara variabelvariabel lainnya.

\section{REFERENSI}

Abbas, D. S., Hakim, M. Z., \& Rustandi, R. (2019). Pengaruh Profitabilitas, Solvabilitas, Opini Audit Dan Reputasi Kantor Akuntan Publik Terhadap Audit Report Lag. Competitive Jurnal Akuntansi Dan Keuangan, 3(1), 21-39. http://dx.doi.org/10.31000/competitive.v3i1.1 531

Angruningrum, S., \& Wirakusuma, M. G. (2013). Pengaruh Profitabilitas, Leverage, Kompleksitas Operasi, Reputasi Kap Dan
Komite Audit Pada Audit Delay. E-Jurnal Akuntansi, 5(2), 251-270. https://ojs.unud.ac.id/index.php/Akuntansi/arti cle/view/7048

Arifuddin, Hanafi, K., \& Usman, A. (2017). Company size, Profitability, and Auditor Opinion Influence to Audit Report Lag on Registered Manufacturing Company in Indonesia Stock Exchange. International Journal of Applied Business and Economic Research, 15(19), 353-367. https://serialsjournals.com/abstract/ 72589_26.pdf

Artaningrum, R. G., \& Wasita, P. A. A. (2020). Pengaruh Profitabilitas, Solvabilitas, Likuiditas, Ukuran Perusahaan, Pergantian Manajemen dan Reputasi KAP Pada Audit Report Lag Perusahaan Perbankan. Jurnal Ekonomi Dan Pariwisata, 15(1), 21-26. https://jurnal.undhirabali.ac.id/index.php/sinte sa/article/view/527

Bahri, S., Hasan, K., \& Carvalho, B. De. (2018). Pengaruh Ukuran Perusahaan, Umur Perusahaan, Profitabilitas, Solvabilitas dan Ukuran Kantor Akuntan Publik terhadap Audit Delay. Conference on Innovation and Application of Science and Technology (CIASTECH 2018), September, 178-185. http://publishing-widyagama.ac.id/ejournalv2/index.php/ciastech/article/view/621

Bawono, \& Ariani. (2018). Pengaruh Ukuran Dan Umur Perusahaan Terhadap Audit Report Lag Moderating. Riset Akuntansi Dan Keuangan Indonesia, 3(2), 118-126. https://doi.org/10.23917/reaksi.v3i2.6878

Cahyanti, D. N., Sudjana, N., \& Azizah, D. F. (2016). Pengaruh Ukuran Perusahaan, Profitabilitas, dan Solvabilitas terhadap Audit Delay (Studi pada Perusahaan LQ 45 Sub-Sektor Bank serta Property dan Real Estate yang Terdaftar di Bursa Efek Indonesia (BEI) Tahun 2010 2014). Jurnal Administrasi Bisnis, 38(1), 6873. http://administrasibisnis.studentjournal.ub. ac.id/index.php/jab/article/view/1483

Chasanah, I. U., \& Sagoro, E. M. (2017). FaktorFaktor Yang Berpengaruh Terhadap Audit Report Lag Pada Perusahaan Lq-45. Jurnal Profita, 5(2), 1-21.

David, \& Aprilyanti, R. (2018). Pengaruh Kualitas Auditor, Profitabilitas Dan Likuiditas Terhadap Audit Delay (Studi Empiris Pada Perusahaan Real Estate yang Terdaftar di BEI Tahun 2013-2017). Jurnal Ilmiah Akutansi Dan Teknologi, 10(2), 1-13. 
Pengaruh Leverage Terhadap Audit Report Lag dengan ... Joice Idarumata Aritonang \& Valentine Siagian

https://doi.org/10.31253/aktek.v10i2.260

Debbianita, Hidayat, V. S., \& Ivana. (2018). Pengaruh Profitabilitas, Solvabilitas, dan Aktivitas Persediaan terhadap Audit Delay pada Perusahaan Retail yang terdaftar di Bursa Efek Indonesia Periode 2014-2015. Jurnal Akuntansi Maranatha, 9(2), 158-169. https://doi.org/10.28932/jam.v9i2.484

Dewangga, A., \& Laksito, H. (2015). Faktor-Faktor Yang Berpengaruh Terhadap Audit Report Lag. Diponegoro Journal of Accounting, 4(3), 1-8. https://doi.org/10.21067/mbr.v4i1.4768

Dura, J. (2017). Pengaruh Profitabilitas, Likuiditas, Solvabilitas, dan Ukuran Perusahaan Terhadap Audit Report lag pada perusahaan yang terdadtar di BEI. Jurnal Ilmiah Bisnis Dan Ekonomi Asia, 11(1), 64-70. https://doi.org/10.32812/jibeka.v11i1.34

Effendi, B. (2018). Profitabilitas, Solvabilitas Dan Audit Delay Pada Perusahaan Consumer Goods Yang Terdaftar Di BEI. Riset \& Jurnal Akuntansi, 2(2), 100-108, ISSN: 2548-9224. https://owner.polgan.ac.id/index.php/owner/ar ticle/view/60

Firmansyah, R., \& Amanah, L. (2020). Pengaruh Profitabilitas, Good Corporate Governance, Leverage, Dan Firm Size Terhadap Audit Report Lag. Jurnal Ilmu Dan Riset Akuntansi (JIRA), 9(3), 1-20. http://jurnalmahasiswa.stiesia.ac.id/index.php/ jira/article/view/2843

Fujianti, L., \& Satria, I. (2020). Firm size, profitability, leverage as determinants of audit report lag: Evidence from Indonesia. International Journal of Financial Research, 11(2). https://doi.org/10.5430/ijfr.v11n2p61

Gunde, Y. M., Murni, S., \& Rogi, M. H. (2017). Analisis Pengaruh Leverage Terhadap Profitabilitas Pada Perusahaan Manufaktur Sub Industri Food and Beverages Yang Terdaftar Di Bei (Periode 2012-2015). Jurnal EMBA: Jurnal Riset Ekonomi, Manajemen, Bisnis Dan Akuntansi, 5(3). https://doi.org/10.35794/emba.v5i3.18382

Harjanto, K. (2017). Pengaruh Ukuran Perusahaan, Profitabilitas, Solvabilitas, dan Ukuran Kantor Akuntan Publik terhadap Audit Delay. Ultima Accounting, 9(8), 33-49. https://doi.org/10.31937/akuntansi.v9i2.728

Himawan, F. A., \& Amanda, R. (2015). Faktor-Faktor Yang Berpengaruh Terhadap Audit Delay (Audit Report Lag) Pada Perusahaan Manufaktur Yang Terdaftar Di Bursa Efek
Indonesia Periode Tahun 2011-2014. ESENSI, 18(3), 14-33. https://ibn.ejournal.id/index.php/ESENSI/article/view/95

Jafira, C. R., Elviani, S., Simbolon, R., Islam, U., \& Utara, S. (2021). Pengaruh Leverage, Working Capital Turnover, Dan Net Profit Margin Terhadap Profitabilitas Pada Perusahaan Bumn Yang Terdaftar Di Bursa Efek Indonesia. Jurnal Riset Akuntansi Multiparadigma (JRAM), 8(1), 45-51. https://doi.org/10.30743/akutansi.v8i1.4064

Kusumah, R. W. R., Febryanto, V., \& Andryana. (2021). Audit Report Lag is Affected by Profitability, Leverage, Audit Opinion, and Company Size. Psychology and Education, $58(3)$, 440-446. https://doi.org/10.17762/pae.v58i3.2750

Lisdara, N., Budianto, R., \& Mulyadi, R. (2019). Pengaruh Ukuran Perusahaan, Laba Perusahaan, Solvabilitas, Dan Ukuran Kantor Akuntan Publik Terhadap Audit Report Lag (Studi Empiris Pada Perusahaan Manufaktur Sub Sektor Makanan Dan Minuman Yang Terdaftar Di Bei Tahun 2015-2017). Jurnal Riset Akuntansi Terpadu, 12(2), 167-179. http://dx.doi.org/10.35448/jrat.v12i2.5423

Menajang, M. J. O., Elin, I., \& Runtu, T. (2019). Analisis Pengaruh Ukuran Perusahaan , Profitabilitas , Dan Solvabilitas Terhadap Audit Report Lag ( Studi Kasus Perusahaan Property Dan Real Estate Yang Terdaftar Di Bursa Efek Indonesia ) Analysis The Effect Of Company Size , Profitability , And Solvency. Journal EMBA, 7(3), 3478-3487. https://doi.org/10.35794/emba.v7i3.24563

Ngadiman, \& Puspitasari, C. (2017). Pengaruh Leverage, Kepemilikan Institusional, Dan Ukuran Perusahaan Terhadap Penghindaran Pajak (Tax Avoidance) Pada Perusahaan Sektor Manufaktur Yang Terdaftar Di Bursa Efek Indonesia 2010-2012. Jurnal Akuntansi, $18(3)$, 408-421. https://doi.org/10.24912/ja.v18i3.273

Octaviani, S., \& Komalasarai, D. (2017). Pengaruh Likuiditas, Profitabilitas, Dan Solvabilitas Terhadap Harga Saham (Studi Kasus pada Perusahaan Perbankan yang Terdaftar di Bursa Efek Indonesia). Jurnal Akuntansi., 3(2), 77-89. https://doi.org/10.30656/jak.v4i1.219

Puspitasari, I. (2020). BEI perpanjang suspensi 6 saham ini karena telat sampaikan laporan keuangan. Retrieved from: 
https://investasi.kontan.co.id/news/bei-

perpanjang-suspensi-6-saham-ini-karena-telatsampaikan-laporan-keuangan

Sastrawan, I. P., \& Latrini, M. Y. (2016). Pengaruh Profitabilitas, Solvabilitas, Dan Ukuran Perusahaan Terhadap Audit Report Lag Pada Perusahaan Manufaktur. Udayana, E-Jurnal Akuntansi Universitas, 17(1), 311-337. https://ojs.unud.ac.id/index.php/Akuntansi/arti cle/view/19792

Sintyana, I. P. H., \& Artini, L. G. S. (2018). Pengaruh Profitabilitas, Struktur Modal, Ukuran Perusahaan Dan Kebijakan Dividen Terhadap Nilai Perusahaan. E-Jurnal Manajemen Universitas Udayana, 8(2), 757. https://doi.org/10.24843/ejmunud.2019.v08.i0 2.p07

Sudradjat, S., Ishak, J. F., Sukmawati, M., \& Syifa, M. N. (2020). The Effect of Profitability, Leverage, Firm Size, Firm Reputation and Institutional Ownership on Audit Report Lag. The Journal of Accounting and Finance, 1(1), 36-40. https://www.ejurnal.plm.ac.id/index. php/JAFIN/article/view/463

Suparsada, N. P. Y. D., \& Putri, I. A. D. (2017). Pengaruh Profitabilitas, Reputasi Auditor, Ukuran Perusahaan, Dan Kepemilikan Institusional Terhadap Audit Delay Pada Perusahaan Manufaktur. E-Jurnal Akuntansi Universitas Udayana, 18(1), 60-87. https://ojs.unud.ac.id/index.php/Akuntansi/arti cle/view/20800

Tampubolon, R. R., \& Siagian, V. (2020). Pengaruh profitabilitas, solvabilitas, likuiditas, dan audit tenure terhadap audit report lag dengan komite sebagai pemoderasi. Jurnal Ekonomi Modernisasi, 16(288), 82-95. https://doi.org/10.21067/jem.v16i2.4954

Tannuka, S. (2018). Solvabilitas, Likuiditas, Dan Ukuran Kap Terhadap Audit Report Lag (Studi Empiris Pada Perusahaan Properti, Real Estate, Dan Konstruksi Bangunan Yang Terdaftar Di Bursa Efek Indonesia Periode 2011-2015). Jurnal Muara Ilmu Ekonomi Dan Bisnis, 2(2), 354-368. https://doi.org/10.24912/jmieb.v2i2.1312

Tuladang, D. O., \& Tipa, H. (2020). Pengaruh Profitabilitas, Solvabilitas Dan Ukuran Perusahaan Terhadap Audit Report Lag Pada Perusahaan Di Bursa Efek Indonesia. Jurnal AKRAB JUARA, 5, 91-103. http://akrabjuara.com/index.php/akrabjuara/art icle/view/1186 